DOI: 10.1515/ausp-2015-0004

\title{
The Census, Maps, and Museums, or a Way of 'Translating' Identity
}

\author{
Vilma-Irén MIHÁLY \\ Sapientia Hungarian University of Transylvania (Miercurea Ciuc, Romania) \\ Department of Humanities \\ vilma_gote@yahoo.com
}

\begin{abstract}
The Census, which aims at recording pieces of information about the members of the population of a country, the historical and geographical maps drawn at the orders of the government, as well as national museums, may be more than the mere sum of the collected data to be presented. Based upon Benedict Anderson's theory, as shown in his book entitled Imagined Communities: Reflections on the Origin and Spread of Nationalism (2006), in my paper I shall try to point at the subtle ways in which official governmental institutions have tried to use the Census, maps and museums in order to shape national identity and influence the image of a nation. Quite often what one can read about the results of the Census, what one can see on a map or encounter in a museum are not objective facts, but items placed there carefully, fulfilling specific purposes. On the one hand, they target the compatriots, on the other hand, the foreigners. Could we say that what we are dealing with here is not only an act of cultural mediation, but also a specific way of 'translating' identity? The next couple of pages shall try to analyze the topic and find an answer to the question above by giving examples.
\end{abstract}

Keywords: identity, national images, maps, museums

Living in the age of globalization and the Internet, travelling, that is being literally or virtually on the road has become a commonplace. No matter if for business or for fun, people travel all over the world, thus meet the other and have the possibility and opportunity to get to know different cultures and customs. Due to this freedom of movement the world opens up to people, and a multitude of information is offered to them. Yet, this does not mean that there is no control over the phenomena. The official data-e.g., the Census, maps-released by the government of a country or the institutions meant for the eyes of tourists-e.g., national museums-are closely supervised.

Benedict Anderson in his book entitled Imagined Communities: Reflections on the Origin and Spread of Nationalism (1983; 2006) examines the Census, maps, 
and museums as institutions of power that helped colonizers in Southeast Asia get and draw a clear picture of the colonized $(2006,164)$. In my paper based upon examples taken from literature I shall try to show that Anderson's theory is to some extent true of the $20^{\text {th }}$ and even the $21^{\text {st }}$ centuries' nation states in Europe which make use of the three institutions mentioned above in order to strengthen their own dominance and integrity, as well as to shape national identity and influence the image of a nation.

In one of my previous studies, ${ }^{1}$ which I shall partially recapitulate here, based upon the theories of Lucian Boia (2012) and Benedict Anderson (2006), I defined the concept of nation as a modern myth. Yet, the meaning of the term myth as a story that provides us with an example dating in illo tempore, prescribing behaviour patterns for today's people, and which is in itself a language, a message referring to human existence (Ries 2007, 11-18), becomes secondary. Far more important is the definition of modern myths as products of our imagination, imagined constructions, meant to manipulate the masses (Barthes 1996).

Both traditional and modern myths somehow fulfil the function of giving protection and hope to people. This is also one of the roles that the concept of nation is meant to play. In the pre-technological era protection was granted by forms of elementary social cohesion: family, the tribe, the rural community, on the one hand, limited the individual, on the other hand, protected him/her from the unseen (Boia 2012, 8). There was also a strong belief in the existence of a higher dimension, the realm of Gods. This transcendental world was responsible for the destiny of humanity; as such it conveyed a meaning to everything in a closed and perfect system (idem). Yet, as these traditional peoples became victims of time and history, their mythical and religious conceptions of the world also grew obsolete. They were replaced by modern myths such as the modern industries, commerce and urbanization. As a consequence of this development, people have been granted more freedom, but have also lost several reference points, so that they have become more and more confused $(2012,9)$. What has always been present in the subconscious of humans is the thirst for absolute knowledge and the desire to overcome all limits imposed on them by existence itself. They seem to have always believed that there is more to life than one can see and that there has to be a higher and nobler purpose hidden in all things $(2012,10)$. Therefore, when the traditional concepts seized to function in a changing, modern world, not only were they replaced by science, progress or any other modern phenomenon but also each of these could easily be sacralised and play the role of the Divine (2012, 10). In this respect the modern phenomenon of the nation ensures solidarity and identity, preserving sacrality. It is a religion "according to which humanity is made up (through divine will or nature) of national entities; history is going to be fulfilled in its universality through each nation apart, and the individual can 
find salvation only within his/her nation, as part of a collective destiny" (2012, 11) [translated by me, V-I. M.].

Besides the interpretation of nation as a modern myth, the concept can be defined as a historical phenomenon that replaces great dynasties and religions. It can be regarded as a collective subject travelling through history together, with members speaking the same language. On this journey the nation becomes self-conscious and self-aware, drawing a line between the self and the other(s), whereby the other can also turn into an enemy. In this respect a nation is also discriminatory: the 'similar' are allies, the 'others' are excluded (Anderson 2006, 1-9).

Thus, we can draw the conclusion that a nation can be best defined as an imagined, limited, sovereign political community (cf. Anderson 2006, 4): imagined because it is impossible for its members to know each and every person of their nation; limited because they need to have frontiers that separate them from other nations, otherwise they would encompass the whole world; sovereign because they can only exist if they are free from others; and its members build a community based upon comradeship and fraternity on the horizontal level (2006, 6-7). This point of view emphasizes the voluntary, constructed and artificial character of the nation, interpreted by Anderson as belonging with kinship and religion, rather than ideologies $(2006,5)$, yet leading Boia to the conclusion that a nation is the projection of an ideology $(2012,15)$. We can witness a reversed perspective: it is not history that makes a nation, but it is the nation which, as it has already been established, will invent its history that is later going to be thought of as standing at its foundation (idem). Concerning the language there is a change of perception as well: a nation is not held together by the language its representatives share, but once established the nation imposes a standard version upon its members-e.g. at the time of the French Revolution in France half of the population spoke different dialects of French, or even other languages such as Italian or German (15-19). In other words, language, religion, ethnic basis or history alone is not sufficient to hold a nation or nation state together. A nation needs an outer voluntary act of creation, a will to exist in order to survive. However, as products of history, but self-made at the same time, nation and nationalism can become obsolete as well, especially if they stick to their limitations and borders so ruthlessly.

The Census, maps, and museums can, on the one hand, hold the nation together fulfilling an internal function, on the other hand, playing an external role as well, they show the others how strong and unified one's own community is. These institutions of power are the means which make the modern myth of the nation, this imagined construction work.

The Census is ordered by the government and conducted by the National Institute of Statistics, and has the task to enumerate the population of the nation state with respect to several criteria, e.g., the number of people living in towns/in the 
countryside, the number of men/women, nationality, religion, mother tongue, etc. The results, besides being factual, are highly depersonalizing as they reduce people to numbers and interpret them in terms of quantity. Moreover, in this manner the different regions are being mapped from on high (Anderson 2006, 169), facilitating an easier organizing of the educational, juridical, health systems and of the police in such a way as to allow the nation state to prosper. The goal is apparently a good one, who would not want to reach prosperity? Yet, let us not forget that the construct is fragile and that there are no ultimately pure nation states, for within a country there are several ethnic and religious minorities, to whom their own imagined national values count just as much. Often after a new Census, governmental structures are changed so as to assimilate and acculturate these minorities, most of the time for fear that they represent a threat to the existence of the nation state.

Similarly to censuses, today's European maps showing space from a bird's-eye view work based on totalizing classifications (cf. 2006, 173). Besides their role of pointing out directions, these maps draw clear lines, borders between nation states. In order to justify the righteousness of the frontiers, historical maps are being used to certify the antiquity of a certain territorial unit (idem, 175). If they are arranged into a chronological order, these maps form the "political-biographical narrative of the realm" (idem), which serves as proof for the nation's continuity.

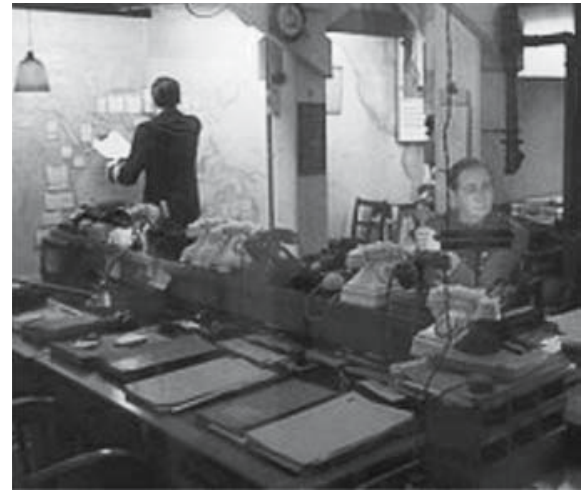

The Map Room of the Cabinet War Rooms ${ }^{2}$

The use of maps as logos which is also a wide-spread phenomenon in our society, can be traced back to colonial states when imperials dyed their colonies on the map with certain colors, e.g., British imperial maps used pink-red for their own colonies, purple-blue for the French, yellow-brown for the Dutch, etc. This way, each territory looked as if it could easily be detached any time from its context becoming a mere sign, no longer a compass.

2 http://en.wikipedia.org/wiki/Imperial_War_Museum, MapRoomCabinetWarRooms20060617_ CopyrightKaihsuTai.jpg. Modifications made by SilkTork. Accessed on 10 April 2014. 


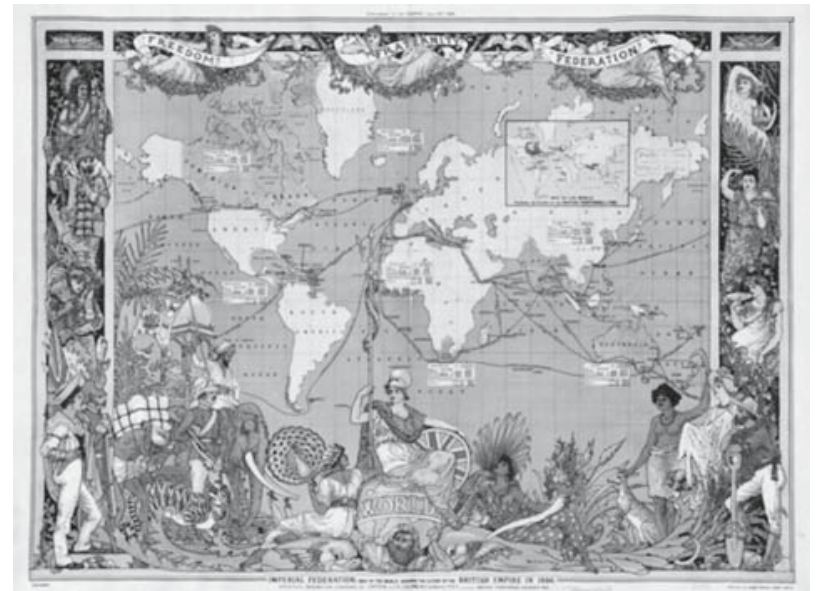

An elaborate map of the British Empire in 1886, marked in the traditional color for imperial British dominions on maps ${ }^{3}$

These colorful puzzle pieces could be reproduced in an infinite number and transferred onto posters, seals, magazines or textbook covers, even key chains (idem). Through their omnipresence these items were often misused ending up to turn the cause they were meant to propagate into the opposite; while they functioned as a reminder of the national feeling, because they were everywhere, people started to ignore them after a while and their meaning became hollow.

Museums in general and national museums in particular are institutions which exhibit national values both for compatriots, as well as for tourists. Yet, the process of museumizing does not only mean putting on a show in order to entertain, but has always had a political side to it as well. Items displayed at museums are often placed there for a specific reason, labeled to be interpreted in the way those at power want to.

In each nation state there has to be a national museum, which, just as the sequence of historical maps, plays the role of proving and fortifying national history and continuity. Paradoxically, the unique nature of these exposed national treasures is betrayed by the very fact that they are reproduced, just as maps, in a variety of products meant for mass consumption.

In conclusion, the three institutions of power, the Census, maps, and museums are interconnected and form a frame which is totalizing and classificatory, called by Anderson a "warp of thinking" (184) applicable to all that the state controls: people, regions, religions, languages, monuments, etc. Once the frame has been drawn, everything has got its well-defined place, can be easily identified and becomes countable, one in a series with a serial number, visible and controllable (185).

3 http://en.wikipedia.org/wiki/British_Empire, Author: Walter Crane (1845-1915) - public domain. Accessed on 10 April 2014. 


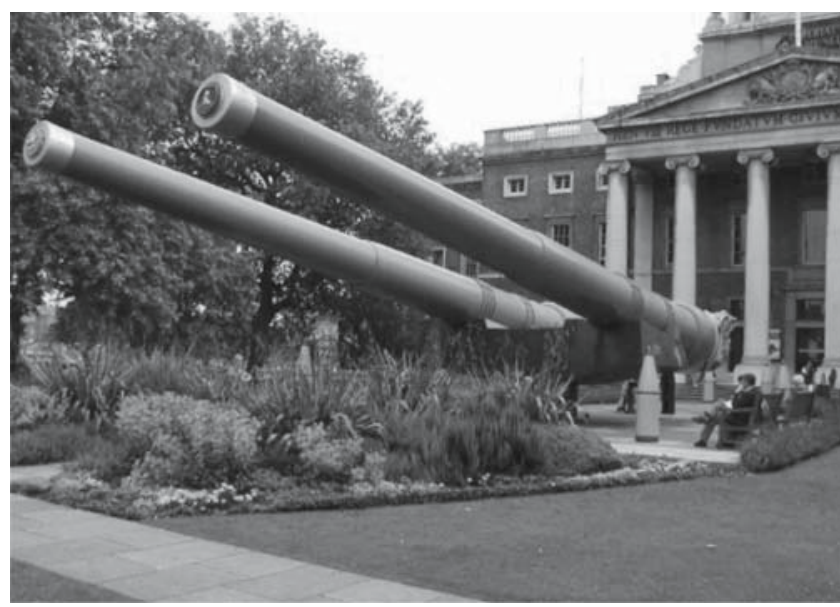

15-inch guns outside the museum; one from HMS Ramillies, the other from HMS Roberts. ${ }^{4}$

Thus, these institutions do not only mediate information, but also translate it to the viewer in a specific language, namely the language of power. The way the Census is interpreted, maps are drawn and objects exhibited, already establishes the perspective of the visitors. It is a conducted translation of national identity, a manipulation of the masses for political reasons.

Literary works quite often have the force to reveal the schemes behind the institutional machinery. In the following I shall name a couple of examples, which come to strengthen the point of view stated above.

Sándor Márai in his travelogue written in form of a diary entitled Europa's Abduction $(1946 / 47)^{5}$ renders his own impressions and experiences while travelling to Western Europe, more precisely to Switzerland, Italy and France right after World War II, when new borders were established and thus, new maps had to be drawn. The journey gives the narrator the opportunity to take a close look at the political, social and mental changes that the war caused in Eastern and Western Europe, to compare these and view the two sides in each other's reflection. During the journey the narrator has the opportunity to visit several museums where he encounters, for example, statues exhibited as a mocking gesture at the address of the past to strengthen the leading nations of the present. When he visits Palazzo Venezia, Mussolini's office, there is a bronze statue of Europa's Abduction dating from the $16^{\text {th }}$ century:

4 http://en.wikipedia.org/wiki/Imperial_War_Museum, source: geograph.org.uk, author: Chris Gunns. Accessed on 10 April 2014.

5 Cf. Mihály (2013). 
In Palazzo Venetia, in Mussolini's office, a small statue from the $16^{\text {th }}$ century. Its title: Ratto d'Europa [Europa's Abduction]. It may be a coincidence, it may be an ironic hint; the exhibition has been organized by the Americans. (Márai 2008, 54) [translated by me, V-I. M.] $]^{6}$

In a very concise manner in this short passage the narrator points at how those in power, the organizers of the event, the Americans, the winners could choose the object to be exposed, and by doing so wanted to transmit a precise message. From the lines above we can conclude that the statue had not been exhibited because of its beauty but because of its title and symbolic value. Had Mussolini tried to abduct the continent of Europe and failed to succeed? Were the Americans mocking at him because of his failure and their own apparent triumph in doing what he had not managed to? Both the questions and answers are implied by the excerpt above. Besides its artistic value, the choice of the statue in the given political context could not have been arbitrary, thus its exposure already contains a readymade translation and interpretation.

Another example taken from literature is Joseph Roth's short story Die Büste des Kaisers [The Bust of the Emperor] (1934/35), ${ }^{7}$ which presents the nostalgic image of the Austro-Hungarian Empire resembling a world without boundaries, where one could travel without a passport and felt at home in every corner of it. This is the very attitude that the main character of the short story, Count Franz Xaver Morstin has, when he returns home after World War I. Only that the circumstances have changed, the Monarchy has fallen, there are nation states now and frontiers. "To a man above nationality" (Roth 1986 [1924], 157) who was accustomed to moving freely, the newly established frontiers of the nation states seem unnatural. They are artificial lines, drawn for political reasons, which do not take into consideration people's feelings or do not follow the (natural) lines of the landscape.

The plot of the short story revolves around the bust of the Emperor that the Count has put up in the little village of Lopatyny, a peripheral territory inhabited by people of different ethnic groups, which within the Monarchy was oppressed by the centre, building a no-man's-land at the frontier. Yet, the representatives of the new nation state cannot allow the old values to survive, because these are threatening the emerging system. The Count and the old world he stands for are subject to ridicule in several instances. Though there is sympathy from the part of the narrator, the facts prove that the old way of life the Count so desperately clings on to is no longer valid. It may have moral value, but it is not taken into consideration. There is a discrepancy between universal moral

6 „A Palazzo Veneziában, Mussolini dolgozószobájában egy kis bronz a XVI. századból. Címe: Ratto d'Europa. Lehet véletlen, lehet gúnyos célzás is; a kiállítást amerikaiak rendezték." 
values of humanity and the machinery of depersonalized history. The outcome is obvious: finally, the Count is asked or ordered, one should rather say, to pull down the Bust of the Emperor. The lost world cannot be brought back. The Count also realizes this fact and decides to bury the bust; he is being accompanied by the simple folk:

The church bells tolled, the larks trilled and the crickets sang unceasingly. The grave was prepared. The coffin was lowered with the flag draped over it, and for the last time Franz Xaver Morstin raised his sabre in salute to his Emperor. The crowd began to sob as though the Emperor Franz Josef and with him the old Monarchy and their own old home had only then been buried. The three pastors prayed.

So the old Emperor was laid to rest a second time, in the village of Lopatyny, in what had once been Galicia. A few weeks later the news of this episode reached the papers. They published a few witticisms about it [...]. (Roth 1986 [1924], 181-182)

Besides the artificial character of the frontiers, and thus implicitly of the maps too, this excerpt is a clear evidence of how monuments, museum pieces are handled/mishandled according to the circumstances, to the change of regimes or to the will of those at power. The same statue can be interpreted in several, at times antithetic ways. While one moment it stands for the Monarchy and is celebrated as a symbol of unity, with the change of regimes it has to be pulled down because it has become a threat to national identity. It cannot even remain there as a piece belonging into a history museum.

These examples have briefly shown us how institutions of power use facts to strengthen their own position. The Census, maps, and museums are not only there to inform us about real data, but they also translate them for us, providing us with the interpretation they want to. The image we get of a nation comes through their lenses, what we get as a result is a translated identity. These thoughts can be developed even further, if we discussed the way literature can also influence/ change these images by translating/interpreting in its turn the mechanism of the institutions of power. 


\section{Works cited}

Anderson, Benedict. 2006. Imagined Communities. Reflections on the Origin and Spread of Nationalism. London and New York: Verso.

Barthes, Roland. 1996. Mythen des Alltags [Mythologies]. Translated by Helmut Scheffel. Frankfurt am Main: Suhrkamp.

Boia, Lucian. 2012. Două secole de mitologie națională. [Two centuries of national mythology,] Bucureşti: Humanitas.

Márai Sándor. 2008. Európa elrablása. Útirajzok. Röpirat a nemzetnevelés ügyében. [Europe's Abduction. Travelogues. Manifest for National Education.] Debrecen: Helikon.

Mihály Vilma-Irén. 2012. Myths of the Nation in Joseph Roth's Die Büste Des Kaisers [The Bust Of The Emperor]. In Philosophical and Humanistic Postmodern Views. International Scientific Conference 2012. Logos. Universality. Mentality. Education. Novelty. Section: Philosophy and Humanistic Sciences, 421-429. Iasi: Lumen.

—. 2013. Europe's Fe/Male Identity. Acta Universitatis Sapientiae, Philologica vol. 5 no. 1: 33-41. http://www.acta.sapientia.ro/acta-philo/philologica-main.htm. Ries, Julien (ed.). 2007. A mítosz az emberiség történetében. [The Myth in the History of Mankind.] Budapest: Officina.

Roth, Joseph. 1986 [1924]. The Bust of the Emperor [Die Büste des Kaisers]. In Hotel Savoy. Translated by John Hoare, 157-183. Woodstock, New York: The Overlook Press. 